\title{
ERP use and value: Portuguese and Spanish SMEs
}

Pedro Ruivo (Instituto Superior de Estatística e Gestão de Informação, Universidade Nova de Lisboa, Lisbon, Portugal)

Tiago Oliveira (Instituto Superior de Estatística e Gestão de Informação, Universidade Nova de Lisboa, Lisbon, Portugal)

Miguel Neto (Instituto Superior de Estatística e Gestão de Informação, Universidade Nova de Lisboa, Lisbon, Portugal)

This is the author peer-reviewed version of the article published by EMERALD as:

Ruivo, P., Oliveira, T., \& Neto, M. (2012). ERP use and value: Portuguese and Spanish SMEs. Industrial Management \& Data Systems, 112(7), 1008-1025.

https://doi.org/10.1108/02635571211254998

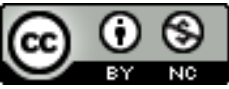

This work is licensed under a Creative Commons Attribution-NonCommercial 4.0 International License. 


\title{
ERP use and value: Portuguese and Spanish SMEs
}

Pedro Ruivo

ISEGI, Universidade Nova de Lisboa

Lisbon, Portugal

pruivo@isegi.unl.pt
Tiago Oliveira

ISEGI, Universidade Nova de Lisboa

Lisbon, Portugal

toliveira@isegi.unl.pt
Miguel Neto

ISEGI, Universidade Nova de Lisboa

Lisbon, Portugal

mneto@isegi.unl.pt

\begin{abstract}
Purpose - Consistent with the diffusion of innovation (DOI) model and resource-based view (RBV) theory, this paper develops a research model for measuring enterprise resource planning (ERP) post-adoption and its consequence on small and medium enterprise (SME) performance.

Design/methodology/approach - The model links six determinants based on DOI to explain 'ERP use' and three determinants based on RBV to explain the 'ERP value', on which nine hypotheses are postulated. Testing was conducted through structural equation modelling, utilizing data from 558 web-surveyed firms in Portugal and Spain.

Findings - Full sample analysis finds that competitive pressure, training, best-practices, compatibility, and efficiency are important antecedents of 'ERP use'. Together with usage, collaboration and analytics capabilities contribute to 'ERP value'. Cross-country analysis reveals that complexity is an important inhibitor for 'ERP use' in Portuguese firms whereas it is a facilitator for Spanish firms. In addition, while for Portuguese firms, compatibility and efficiency are significant, they are not for Spanish. For 'ERP value', while use and collaboration are more important for Portuguese firms, analytics is more important for Spanish.

Research limitations/implications - This study provides insight into how SMEs use and value ERP, however, we cannot speak empirically on the issue of whether value is sustained, or on maturity stages, or on the impact of different industries.

Originality/value - This is the first empirical research study on Iberian SMEs, thus adding a cross-country dimension to the innovation diffusion literature. Unlike the typical focus on ERP adoption found in the literature, this study focuses on post-adoption stages, linking actual usage with value.
\end{abstract}

Keywords - ERP, SMEs, diffusion of innovation, resource-based view, post-adoption, use, value.

Paper type - Research paper. 


\section{Introduction}

As suggested in the literature, innovation is more and more identified as the transformative force that creates and shapes new economies in today's digital world. Firms often adopt information systems (IS) to upgrade or improve their business performance and be more competitive (Ho and Tai, 2004). Davenport (1998) qualified enterprise resource planning (ERP) systems as the most important development in enterprises' use of information technology (IT). ERP's main purpose is to integrate functions of financial management, supply chain management, and customer relationship management to the greatest extent possible. Such systems manage both information and resources by supporting execution of operational transactions and advanced planning, alongside real-time data access (Klaus et al., 2000).

As with many other technological innovations, ERP systems were initially implemented mostly in large organizations, and this has probably been the main reason for research to focus on large enterprises. Although small and medium enterprises (SMEs) have been adopting ERP systems for many years, the literature reveals that little attention has been given to research on ERP in SMEs, and less on cross-national studies. Moreover, according to the European Commission (2011), 99\% of all European firms have fewer than 250 employees, and both Portugal and Spain adhere to this profile, and with the same percentage. Because SMEs are the backbone of the economy, important for increasing productivity and gaining competitive advantage, as well as being important drivers of innovation and transformation, it is valuable to study ERP at the SME level across countries (Hitt et al., 2002, Raymond and Uwizeyemungu, 2007, Chuang et al., 2009, Maguire et al., 2010).

As the impact of IT systems on a firm's performance is mostly long term and indirect, measures of the value to business are linked primarily to system usage (Devaraj and Kohli, 2003, Zhu and Kraemer, 2005). The current investigation explores an alternative way to understand and measure IT value by studying ERP in its post-adoption phases; use and value. We develop and test a model based on the Diffusion of Innovation (DOI) model and resource-based view (RBV) theory.

The theoretical perspectives and research model proposed to explain use and value are outlined in next two sections. The appropriateness of the model is then tested using a sample of 588 firms. Tests for differences based on Portugal and Spain are also conducted. Finally, we discuss our results and offer implications and conclusions.

\section{Theoretical perspectives}

\subsection{ERP use and diffusion of innovation}

Whereas ERP implementation refers to the stage of system planning, configuration, testing, and "going-live", ERP use means ERP utilization. It refers to the experience of managing the operation of the system software throughout the system's post-implementation stages (Nah et al., 2004, Liang et al., 2007). In line with literature we consider ERP to be a type of innovation that is implanted in a firm's core business processes in order to leverage performance (Rajagopal, 2002, Zhu and Kraemer, 2005). Not only does it extend basic business and streamline integration with suppliers and customers, it also directs system usage to the firm's performance. Rogers' (1995) DOI model seeks to explain and predict if and how an innovation is used within a social system, with regard to performance at the firm level. Research conducted by Bradford and Florin (2003), Waarts et al. (2002) and Light and Papazafeiropoulou (2004) verifies DOI determinants regarding ERP use. Considering their findings, we believe that DOI has the potential to provide a favourable framework for explaining ERP use.

\subsection{ERP value and resource-based view}

While ERP use refers to the production stage of system usage among firms actually using ERP in their daily business activities, ERP value refers to firms' ability to utilize ERP to create a competitive advantage. It refers to the ERP impact on a firm's performance, throughout the system life in the post-adoption stages (Rhodes $e t$ al., 2009). Since ERP's value relies on how firms strategically exploit the system, firm's performance in a competitive environment is a subject that draws much attention and some authors attempt to build explanatory 
theories. One of the most recognized is the RBV theory, which states that firm-specific resources determine the firm's performance. It is linked to the competitive advantage approach to strategic management and can explain sustained advantages (Hedman and Kalling, 2003). In the IS literature, the RBV has been used to analyse IT capabilities as a resource and to explain IT business value. That is, IT business value depends on the extent to which IT is used in the key activities of the firm. The greater the use, the more likely the firm is to develop unique capabilities from its IT business applications (Bharadwaj, 2000, Zhu and Kraemer, 2005, Antero and Riis, 2011). Hedman and Kalling (2003) and Fosser et al. (2008) used RBV to extend Mata et al.'s (1995) framework for organizational and business resources and concluded that ERP systems are IT resources that can lead to sustained, competitive advantages. With this in mind, our theoretical model for ERP value will include variables that input value to ERP and positively impact the predisposition to extract value from the system.

\section{Research model and hypotheses}

The post-adoption model presented in Figure 1 outlines our proposal that the DOI model explains 'ERP use' and RBV theory explains 'ERP value'. The left-hand side shows the extent of 'ERP use', influenced by six factors embedded in the DOI context: compatibility, complexity, efficiency, best-practices, training and competitive pressure. On the right-hand we postulate that 'ERP value' is explained by: 'ERP use', collaboration, and analytics.

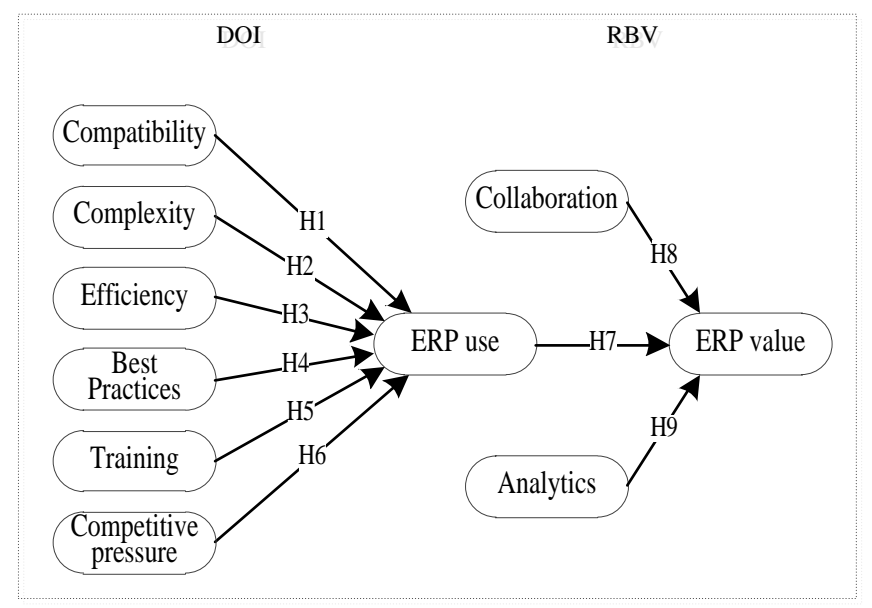

Figure 1. Research model

\subsection{Hypotheses to explain use}

Based on DOI literature, compatibility and complexity have shown consistent associations with IS adoption. O'Leary (2000) and Bradford and Florin (2003) report that best-practices, training, and competitive pressure are also important dimensions for ERP usage. We contribute to this research by including the level of transactional efficiency as an important dimension that will influence ERP usage, and therefore postulate six hypotheses.

\section{Compatibility}

Compatibility is measured by the degree to which the ERP system matches IT features, such as compatibility with hardware and other software. Bradford and Florin (2003) and Elbertsen et al. (2006) concluded that the degree of compatibility of ERP systems with existing software and hardware will have a positive relationship with implementation success (system adoption and use). We thus formulate the first hypothesis:

Hypothesis 1. Firms having ERP systems with greater compatibility are more likely to achieve more ERP use.

\section{Complexity}

Cooper and Zmud's (1990) research indicates that system usage enhances job performance. Studies conducted by Kositanurit et al. (2006) and Chang et al. (2011) conclude that ERP complexity is a major factor affecting 
user performance. Bradford and Florin (2003) concluded that ERP complexity is a critical factor for successful implementation. When users find it difficult to obtain the desire result from the ERP, frustration and unwillingness to use the system generally result. When users are comfortable using ERP, it scales up the users' knowledge of the system and, so too, their skills in manipulating the system in effective ways. Moreover, it prepares users to comprehend the system trends sufficiently and comprehensively (Yu, 2005). Based upon this, we state our second hypothesis:

Hypothesis 2. Firms having ERP systems that are perceived to be complex are less likely to use ERP.

\section{Efficiency}

Bendoly and Kaefer (2004) assessed transactional efficiency on data posting and found that its communication over the ERP improves the firm's overall performance. Rajagopal (2002) found that transactional efficiency has a direct influence on ERP use. Business process benefits of ERP investment include transactional efficiency, where reliability effectiveness on the application improves user confidence. Along the same lines, Gattiker and Goodhue (2005) found that coordination improvements and efficiency are significant benefits to ERP use. Taking this background into account, we construct our third hypothesis:

Hypothesis 3. Firms having ERP systems with greater transactional efficiency are more likely to use ERP.

\section{Best Practices}

From the perspective of business process reengineering, there are two main options in implementing ERP systems: modify (customization) the ERP package to suit the firm's requirements (with high costs), or the implementation of an ERP package with minimum deviation from the standard settings (with lower costs) (Davenport, 1998). According to Light and Papazafeiropoulou (2004), Velcu (2007) and Chou and Chang (2008) the reason for adopting 'best practice' is the belief that ERP design does things in the right way, that is, using the standard business process embedded in the software package without or with low minimum deviation from the standard. In line with Wenrich and Ahmad (2009) and Maguire et al. (2010), firms that implement industry best-practices dramatically reduce risk and time-consuming project tasks such as configuration, documentation, testing, and training. Thus, we postulate that firms that opt to implement ERP based on standard best-practices will use the system more. Based on these considerations, we formulate the fourth hypothesis:

Hypothesis 4. Firms with a greater degree of business process fit to standard ERP 'best-practices' are more likely to use ERP.

\section{Training}

Several researchers, including O'Leary (2000), Bradford and Florin (2003), and Maguire et al. (2010) state that one of the main determinants for successfully adopting, using, and benefiting from ERP systems is the training of the users. The state of preparedness of users to meet situations and carry out a planned sequence of actions without upstream errors has an instantly positive impact on business. These researchers state that the level of the training programme that employees undergo with respect to ERP systems should focus on content, format and applicability, providing knowledge and skills to employees on how to use the system that improves familiarity and boost its use. We therefore postulate that firms with a higher level of training programme raise employees' readiness to use ERP. In line with research, we construct the fifth hypothesis:

Hypothesis 5. The level of firms training programme will have a positive relationship with ERP use.

\section{Competitive pressure}

Competitive pressure has long been recognized in the innovation diffusion literature as an important driver of technology diffusion (Bradford and Florin, 2003, Zhu and Kraemer, 2005, Oliveira and Martins, 2010b). These studies have shown that innovation diffusion is accelerated by the competitive pressure in the environment. Thus, we postulate that competitive pressure plays an important role in pushing firms toward using ERP systems. In line with research, we construct the sixth hypothesis:

Hypothesis 6. Firms facing higher competitive pressure are more likely to use ERP. 


\subsection{Hypotheses to explain value}

From the RBV perspective, some (albeit few) researchers have shown that amount of use is associated with firm performance (Mabert et al., 2001). We contribute to this research by considering collaboration and analytics to be additional important dimensions that will influence ERP value, and therefore postulate three hypotheses.

\section{ERP use}

The link between ERP use and ERP value is a measure of the breadth and depth of how users work with the system and of decision-making based on analytical indicators. To explain the connection between usage and value, we support our proposition on RBV; the greater the extent of ERP use, the greater the likelihood that firms will create capabilities that are rare, inimitable, valuable, and sustainable, thereby contributing to value creation. A study conducted by Shahin and Ainin (2011) found that user fit on ERP is critical in explaining the ERP usage, and a successful adaptation with firms' processes and data flow from other IS makes ERP worthwhile. With ERP systems (and their integration capability with other systems) firms can form a specific resource that guides both internal and external collaboration and provides the repository to perform business analyses. As a result, it is only when firms are actually using ERP systems to conduct business that ERP can have an impact on firm performance. Obviously, without system usage it is impossible for ERP to generate any impact on firm performance (Devaraj and Kohli, 2003, Zhu and Kraemer, 2005). These researchers demonstrate that there is a strong link between system use and system impact. In line with literature, we formulate the seventh hypothesis as:

Hypothesis 7. Firms with greater ERP use are more likely to generate higher ERP value.

\section{Collaboration}

Calisir and Calisir (2004), Gattiker and Goodhue (2005), and Ruivo and Neto (2011) support the conclusion that ERP systems help users to collaborate; up, down, and across their department, company, and industry ecosystem, increasing their productivity and the health of their firms and business partners. ERP is a kind of gateway to unique functions. That is, ERP is the sine qua non factor for others (both humans and applications) to collaborate with ERP - from meeting service-level agreements to promoting enterprise performance. ERP systems provide users with a structured communication channel with the right information at the right time, resulting in increased efficiency and effectiveness. We believe that partnering with ERP and cross-group collaboration amplifies the ERP value. Therefore, and in line with RVB theory, we postulate the eighth hypothesis:

Hypothesis 8. Firms' greater collaboration ERP systems are positively associated with higher ERP value.

\section{Analytics}

Davenport and Harris (2007) stated that "analytics is not new" but that not many firms give it priority. Firms generally use business analytics to leverage the investment they have made in ERP systems. In seeking to gain competiveness, firms use integrated data and set analytics as a strategic initiative. The common data model and visibility across functional departments allows firms' metrics to be unified and consistent. Although ERP systems are essentially transaction-focused on internal data, those firms that use ERPembedded analytics capabilities can easily and quickly use data for managerial decision making and realize an advantage in their pursuit of sustainable performance (Chiang, 2009, Ruivo and Neto, 2011). In line with RVB theory and literature, we believe that analytics provides users with unique business insight information, and therefore we construct the ninth hypothesis:

Hypothesis 9. Firms with greater levels of analytical information extracted from ERP are positively associated with higher ERP value.

\section{ERP value measurement}

Studies conducted by Park et al. (2007) and Chang et al. (2011) concluded that ERP value output can be measured by three dimensions: individual productivity, customer satisfaction, and management control. Furthermore, both Zhang et al. (2005) and Bradford and Florin (2003) established user satisfaction as an 
important dimension of ERP value. In our study, we assess the positive impact of an ERP system on firm performance by user satisfaction, individual productivity, customer satisfaction, and management control.

\subsection{Hypothesis to explain the differences between countries}

According to the European Commission (2011), although Spain is five times larger than Portugal, it had a negative growth rate of Gross-Value Added (GVA) produced by private businesses in 2010, while Portugal had a positive growth rate. Rogers (1995) and Zhu and Kraemer (2005) found that diffusion occurs differently across countries due to different environments. Looking specifically at the use of ERP, as country home market dimension and consumer product demand define industry type, firm's strategies, and country overall GVA, it therefore shapes ERP value across countries. In this line, we wish to understand the differences of ERP use and value across countries and therefore we construct the tenth hypothesis, as a result:

Hypothesis 10. The antecedents of ERP use and value will differ for Portuguese and Spanish SMEs.

\section{Research methodology and data}

A survey methodology is proposed for data collection to validate the research model and test its nine hypotheses. Each survey item-question was reviewed for content validity by ERP experts; three academics and two consultants. The initial questionnaires were pilot tested on 10 firms, and some items were revised for clarity. The finalized questionnaire was designed to be answered in 15 minutes (Malhotra and Birks, 2007). With the assistance of International Data Corporation (IDC) we conducted a web-survey during September and October 2011. To ensure the generalization of the survey results, the sampling was stratified by country (Portugal and Spain), by firm size (fewer than 250 employees), and by industry (finance, distribution, manufacturing, and professional services). Questionnaires were translated into the two languages and sent only to firms that use ERP in conducting their business. In total, 1400 (1000 Spanish and 400 Portuguese) firms received the email survey, and 588 valid responses were returned (424 Spanish and 134 Portuguese). Table I shows the sample characteristics; approximately $70 \%$ of Portuguese firms responded that they had been using ERP for less than five years, while Spanish firms expressed $40 \%$. The wide range of the respondent and industry types, suggests the good quality of the data source.

\begin{tabular}{|c|c|c|c|c|c|c|}
\hline \multirow[b]{2}{*}{ Characteristics } & \multicolumn{2}{|c|}{ Full sample $(\mathrm{N}=558)$} & \multicolumn{2}{|c|}{ Portugal $(\mathrm{N}=134)$} & \multicolumn{2}{|c|}{ Spain $(N=424)$} \\
\hline & $\begin{array}{c}\text { Frequency } \\
(\%)\end{array}$ & $\begin{array}{c}\text { Cumulative } \\
(\%)\end{array}$ & $\begin{array}{c}\text { Frequency } \\
(\%)\end{array}$ & $\begin{array}{c}\text { Cumulative } \\
(\%)\end{array}$ & $\begin{array}{c}\text { Frequency } \\
(\%)\end{array}$ & $\begin{array}{c}\text { Cumulative } \\
(\%)\end{array}$ \\
\hline \multicolumn{7}{|c|}{ Number of years using ERP } \\
\hline$<2$ & 28.0 & 28.0 & 36.6 & 36.6 & 19.7 & 19.7 \\
\hline $2-5$ & 26.8 & 54.7 & 33.3 & 69.5 & 20.3 & 39.9 \\
\hline $5-10$ & 31.4 & 86.1 & 27.5 & 97.0 & 35.3 & 75.2 \\
\hline$>10$ & 13.9 & 100.0 & 3.0 & 100.0 & 24.8 & 100.0 \\
\hline \multicolumn{7}{|l|}{ Industry type } \\
\hline Distribution & 29.6 & 29.6 & 28.4 & 28.4 & 30.0 & 30.0 \\
\hline Manufacturing & 30.8 & 60.4 & 23.9 & 52.2 & 33.0 & 63.0 \\
\hline Finance & 19.2 & 79.6 & 24.6 & 76.9 & 17.5 & 80.4 \\
\hline Services & 20.4 & 100.0 & 23.1 & 100.0 & 19.6 & 100.0 \\
\hline \multicolumn{7}{|l|}{ Respondent type } \\
\hline CEO, owner & 18.5 & 18.5 & 20.9 & 20.9 & 17.7 & 17.7 \\
\hline IT/IS manager & 27.4 & 45.9 & 27.6 & 48.5 & 27.4 & 45.0 \\
\hline Finance manager & 19.9 & 65.8 & 20.1 & 68.7 & 19.8 & 64.9 \\
\hline Sales manager & 22.9 & 88.7 & 23.1 & 91.8 & 22.9 & 87.7 \\
\hline Manufacturing manager & 11.3 & 100.0 & 8.2 & 100.0 & 12.3 & 100.0 \\
\hline
\end{tabular}

Table I. Characteristics of the samples

The constructs were operationalized on the basis of a literature review (shown in Appendix A). Constructs were measured using a survey instrument and multiple indicator items to strengthen validity. Whereas the 'ERP use' construct was measured by items calling for responses in percentages, all other constructs were measured by item responses on a five-point Likert scale ranging from $1=$ low to $5=$ high. The control variables used were country, size, and industry type. 


\section{Data analysis and results}

A structural equation model was conducted to empirically assess the constructs theorized above. Because our purpose is to exam the validity of the constructs and does not require normal distribution for the variables, we used the partial least squares (PLS) as implemented in the software SmartPLS. We performed the Kolmogorov-Smirnov test and confirmed that none of the items measured are distributed normally $(\mathrm{p}<0.001)$. In accordance with Chin (1998), factor loadings should be at least 0.6 and preferably greater than 0.7. For this reason CB3, CX1, TN1, CP2, and ERPU1 question-items of Appendix A were excluded from our research model following the PLS model estimation due to low loadings. We retain the items presented in Table II, except for BP2 (0.691), all other items have loadings above 0.7 and are significant at $(\mathrm{p}<0.001)$. Furthermore, Table II shows that composite reliability (CR) and average variance extracted (AVE) for each construct are above the cut-off of 0.7 and 0.5 , respectively (Hair et al., 1998).

\begin{tabular}{|c|c|c|c|c|c|c|}
\hline \multirow{2}{*}{ Item } & \multicolumn{2}{|c|}{ Full sample $(\mathrm{N}=558)$} & \multicolumn{2}{|c|}{ Portugal ( $N=134)$} & \multicolumn{2}{|c|}{ Spain $(N=424)$} \\
\hline & Loading & t-Stat* & Loading & t-Stat* & Loading & t-Stat* \\
\hline CB1 & 0.978 & 480.195 & 0.925 & 7.360 & 0.953 & 178.696 \\
\hline $\mathrm{CB} 2$ & 0.981 & 637.229 & 0.991 & 12.141 & 0.963 & 231.001 \\
\hline $\mathrm{CX} 2$ & 0.771 & 3.734 & 0.936 & 97.797 & 0.813 & 10.621 \\
\hline $\mathrm{CX} 3$ & 0.965 & 7.020 & 0.919 & 93.032 & 0.923 & 24.525 \\
\hline $\mathrm{EF} 1$ & 0.790 & 29.259 & 0.764 & 32.003 & 0.823 & 36.359 \\
\hline $\mathrm{EF} 2$ & 0.796 & 26.170 & 0.768 & 26.920 & 0.810 & 34.927 \\
\hline $\mathrm{EF} 3$ & 0.842 & 30.017 & 0.880 & 61.194 & 0.806 & 26.461 \\
\hline BP1 & 0.820 & 44.817 & 0.796 & 33.578 & 0.820 & 39.199 \\
\hline BP2 & 0.716 & 19.890 & 0.691 & 18.552 & 0.719 & 18.002 \\
\hline $\mathrm{BP} 3$ & 0.825 & 38.751 & 0.880 & 60.196 & 0.811 & 33.816 \\
\hline $\mathrm{TN} 2$ & 0.939 & 173.910 & 0.954 & 269.978 & 0.931 & 148.220 \\
\hline $\mathrm{TN} 3$ & 0.936 & 156.885 & 0.961 & 345.770 & 0.936 & 148.252 \\
\hline $\mathrm{CP} 1$ & 0.957 & 168.484 & 0.983 & 161.226 & 0.948 & 193.680 \\
\hline $\mathrm{CP} 3$ & 0.859 & 48.499 & 0.784 & 23.648 & 0.878 & 61.211 \\
\hline ERPU2 & 0.894 & 117.847 & 0.894 & 137.936 & 0.900 & 114.363 \\
\hline ERPU3 & 0.871 & 84.732 & 0.875 & 84.041 & 0.851 & 62.882 \\
\hline $\mathrm{CO} 1$ & 0.893 & 151.719 & 0.898 & 188.766 & 0.892 & 150.663 \\
\hline $\mathrm{CO} 2$ & 0.828 & 72.089 & 0.887 & 156.042 & 0.803 & 59.303 \\
\hline $\mathrm{CO} 3$ & 0.808 & 44.080 & 0.818 & 53.113 & 0.805 & 44.901 \\
\hline AN1 & 0.829 & 72.541 & 0.875 & 111.851 & 0.816 & 62.040 \\
\hline AN2 & 0.883 & 91.012 & 0.903 & 103.026 & 0.878 & 89.616 \\
\hline AN3 & 0.777 & 49.521 & 0.874 & 84.742 & 0.746 & 41.004 \\
\hline ERPV1 & 0.725 & 46.535 & 0.747 & 52.967 & 0.721 & 45.912 \\
\hline ERPV2 & 0.900 & 156.543 & 0.927 & 225.381 & 0.893 & 133.216 \\
\hline ERPV3 & 0.846 & 92.060 & 0.862 & 87.722 & 0.841 & 93.742 \\
\hline ERPV4 & 0.745 & 48.323 & 0.703 & 34.468 & 0.754 & 48.440 \\
\hline Construct & CR & AVE & CR & AVE & CR & AVE \\
\hline Compatibility (CB) & 0.980 & 0.960 & 0.958 & 0.919 & 0.957 & 0.917 \\
\hline Complexity (CX) & 0.864 & 0.763 & 0.925 & 0.860 & 0.861 & 0.757 \\
\hline Efficiency $(\mathrm{EF})$ & 0.851 & 0.656 & 0.847 & 0.649 & 0.854 & 0.661 \\
\hline Best Practices (BP) & 0.831 & 0.622 & 0.834 & 0.628 & 0.827 & 0.616 \\
\hline Training (TN) & 0.936 & 0.879 & 0.957 & 0.917 & 0.931 & 0.871 \\
\hline Competitive Pressure (CP) & 0.905 & 0.827 & 0.882 & 0.791 & 0.910 & 0.835 \\
\hline ERP Use (ERPU) & 0.876 & 0.779 & 0.878 & 0.782 & 0.868 & 0.767 \\
\hline Collaboration $(\mathrm{CO})$ & 0.881 & 0.712 & 0.902 & 0.754 & 0.873 & 0.696 \\
\hline Analytics (AN) & 0.870 & 0.690 & 0.915 & 0.782 & 0.856 & 0.665 \\
\hline ERP Value (ERPV) & 0.881 & 0.652 & 0.886 & 0.664 & 0.880 & 0.648 \\
\hline
\end{tabular}

Table II. PLS factor loading, composite reliability, and average variance extracted of full and country samples

In short, our measurement model satisfies convergent validity criteria. Consequently, the constructs developed can be used to test the conceptual model and its hypotheses. 
We tested the conceptual model by using both the full sample and the sample split between Portugal and Spain. Figure 2 shows the path coefficients and t-statistics (in parentheses) derived from bootstrapping (300 resamples), as well as the $\mathrm{R}^{2}$ values for dependent constructs.

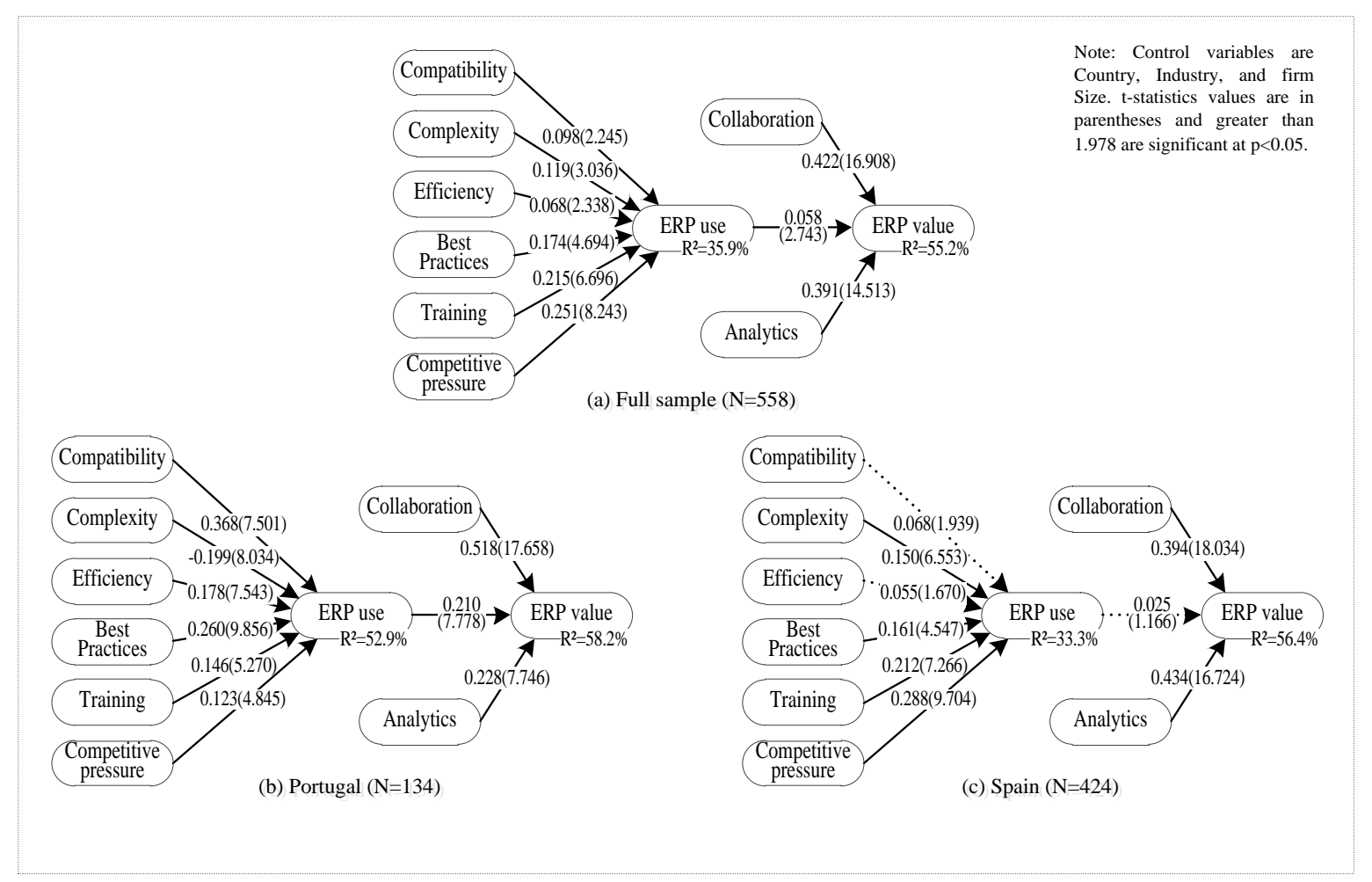

Figure 2. Path models of full sample and by country

The analysis of hypotheses for the full sample was based on the examination of the standardized paths shown in Figure 2(a). For 'ERP use', all six DOI determinants; compatibility, complexity, efficiency, best-practices, training and competitive pressure, have positive and statistically significant paths leading to the dependent construct. Although the path associated with complexity is statistically significant, it does not have the negative sign that we expected. Therefore, all hypotheses (except H2) dealing with 'ERP use' are supported. In addition, the model shows a significantly positive link from use to value (0.058), thus supporting $\mathrm{H} 7$. Collaboration and analytics are also shown to have significantly positive associations with 'ERP value'; hence, $\mathrm{H} 8$ and $\mathrm{H} 9$ are supported. To assess model fit, we present $\mathrm{R}^{2}$ values in Figure 2 (a), which indicates how well the antecedents explain the dependent construct. An examination of the $\mathrm{R}^{2}$ values shows that all six DOI determinants explains the variability of 'ERP use' in 35.9\%, and 'ERP use', collaboration and Analytics determinants explain the variability of 'ERP value' in 55.2\%, suggesting a good fit for the model.

The analysis of hypotheses on the Portuguese and Spanish subsamples was also based on the examination of the standardized paths shown in Figures 2(b) and 2(c), respectively. In the Portuguese subsample, for 'ERP use', although complexity has a negative path while the other five factors have positive paths, all six DOI determinants are statistically significant. Thus, H1 to H6 regarding 'ERP use' are supported. In addition, the model indicates a strong link from 'ERP use' to 'ERP value' (H7). Although collaboration (H8) has a stronger relationship (0.518) with 'ERP value' than analytics (H9), both H8 and H9 are supported. Regarding the Portuguese subsample, based on this model $52.9 \%$ of the 'ERP use' variability was explained by six determinants, and $58.2 \%$ of the 'ERP value' variability was explained by three determinants.

In the Spanish subsample, for 'ERP use', although all six DOI determinants are positive, only four are found to be significant; compatibility and efficiency are insignificant. Complexity was expected to be negative and therefore, H4, H5, and H6 for 'ERP use' are supported. The model shows a not significant link between 'ERP 
use' and 'ERP value', hence H7 is not confirmed. As in the Portuguese subsample, the Spanish shows a significantly positive association of collaboration and analytics with 'ERP value'. Hence, H8 and H9 are supported. For Spain, best-practices, training, and competitive pressure explain the variability of 'ERP use' in $33.3 \%$ and, 'ERP use', collaboration, and analytics explain the variability of 'ERP value' in $56.4 \%$.

In a deeper analysis, we tested the differences between the path coefficients across the Portugal and Spain subsamples. Table III shows that regarding 'ERP use'; training has no statistically significant differences ( $>0.10$ ) between countries, being equally important for both Portuguese and Spanish firms. Whereas bestpractices, compatibility, and efficiency are more important factors to Portuguese firms, competitive pressure is more important to Spanish firms. Moreover, complexity is found to be an important inhibitor for Portuguese firms and a facilitator for Spanish. Regarding 'ERP value'; whereas 'ERP use' and collaboration are more important for Portuguese firms, analytics is more important to Spanish firms.

\begin{tabular}{lcccccc} 
& \multicolumn{2}{c}{ Portugal } & \multicolumn{2}{c}{ Spain } \\
& $\begin{array}{c}\text { Path } \\
\text { coeff. }\end{array}$ & $\begin{array}{c}\text { SE from } \\
\text { bootstrap }\end{array}$ & $\begin{array}{c}\text { Path } \\
\text { coeff. }\end{array}$ & $\begin{array}{c}\text { SE from } \\
\text { bootstrap }\end{array}$ & t-Stat. & p (2-tailed) \\
\hline Compatibility -> ERP Use & 0.368 & 0.049 & 0.068 & 0.035 & 4.989 & 0.000 \\
Complexity -> ERP Use & -0.199 & 0.025 & 0.150 & 0.023 & -10.359 & 0.000 \\
Efficiency -> ERP Use & 0.178 & 0.024 & 0.055 & 0.033 & 3.021 & 0.003 \\
Best Practices -> ERP Use & 0.260 & 0.026 & 0.161 & 0.035 & 2.260 & 0.024 \\
Training -> ERP Use & 0.146 & 0.028 & 0.212 & 0.029 & -1.625 & 0.104 \\
Competitive -> ERP Use & 0.123 & 0.025 & 0.288 & 0.030 & -4.214 & 0.000 \\
ERP Use -> ERP Value & 0.210 & 0.027 & 0.025 & 0.021 & 5.383 & 0.000 \\
Collaboration -> ERP Value & 0.518 & 0.029 & 0.394 & 0.022 & 3.409 & 0001 \\
Analytics -> ERP Value & 0.228 & 0.029 & 0.434 & 0.026 & -5.269 & 0.000 \\
\hline
\end{tabular}

Table III. Results of pooled error term t-Tests by subgroup

Overall, the above results provide support for the cross-country differences in the determinants shaping ERP use and value in which firms adopt IT, thereby supporting Hypothesis 10.

\section{Discussion}

The purpose of this paper is to identify the determinants that explain ERP post-adoption with regard to usage and value and to determine the magnitude of variations across Portugal and Spain. Empirical results support our theoretical model, and all hypotheses have been tested on full sample and subsamples. Both academic and managerial implications are discussed below.

\section{Full sample}

As indicated by their significant and positive paths in Figure 2(a), amongst the DOI determinants, competitive pressure is found to have the most significant impact on the degree of 'ERP use', followed by training and best-practices. That is, firms facing greater competitive pressure tend to achieve a greater extent of 'ERP use', as do firms with better trained users, as well as using ERP systems with standard best-practices. Our study provides evidence that system compatibility and transactional efficiency are important drivers for system usage. That is, as daily operations are more and more managed through ERP use, and compatibility issues are resolved, ERP becomes more stable, increasing the reliability and effectiveness for its usage, thus becoming a necessity.

Contrary to the conclusions of Bradford and Florin (2003), Kositanurit et al. (2006), and Chang et al. (2011), and our predictions, our results reveal a positive effect of system complexity on 'ERP use'. It has been widely 
believed that complexity of business applications is an inhibitor to use, but our results provide evidence that for Spanish firms system complexity is not an inhibitor, such as it is for Portuguese firms.

As shown in Figure 2(a), the 'ERP use' and 'ERP value' relationship is found to be a significant and positive link from use to value, supporting our research design, in which use explains the value, in accordance with Devaraj and Kohli (2003) and Zhu and Kraemer (2005).

Both collaboration and analytics capabilities are found to be a significant and positive links to 'ERP value'. As discussed in the "hypothesis to explain value" subsection (3.2), while collaborating with colleagues, system, suppliers, partners, and customers increase productivity, analytics provides greater business insight for better decision making processes. As a result, these two ERP enhanced capabilities help firms to improve performance because they are firm specific, difficult to imitate, and less mobile across firms, which is consistent with the RBV theory.

\section{Differences between Portugal and Spain.}

Our study finds that for Portuguese SMEs the ERP value relies greatly on the capacity of users to collaborate to meet service levels, mainly because transactional data become visible to the supply chain, decreasing the bullwhip effect. Since quality of the data (and thus also the quality of its ramifications) is largely dependent on using the system correctly, the 'ERP use' is also perceived as an important determinant for ERP value. Subsequently, as data become available and transformed into business information, allowing reporting, analytics capabilities are considered alongside as an important factor of ERP value. For Spanish SMEs the ERP value is composed largely of system analytics capabilities to make full use of operational data, and generate more detailed reports to support decision-making and resource planning in an improved manner followed by collaboration, to serve new possibilities for using information to improve transparency and business processes.

Contrarily to Portuguese SMEs, the greater ERP use amongst Spanish firms is not perceived as an important factor to generate value from ERP. This difference might be explained by the fewer number of years in which Portuguese firms have been using ERP; whereas the Portuguese subsample shows that $70 \%$ of firms have been using ERP systems for less than 5 years, the Spanish subsample shows $40 \%$. (Table I). That is, utilizing the ERP logic for more years, the perception of 'ERP use' upon 'ERP value' drops in importance next to collaboration and analytics capabilities. In line with Hakkinen and Hilmola (2008) the perception on ERP success usage drops from the 'shakedown' phase (when the system was just adopted) to post go-live phase (a few years after the system start been utilized). Moreover, Buonanno et al. (2005) state that ERP starters confer more value to collaboration because it is often connected to the organizational enhancements, whereas firms using ERP for more years confer to fully exploit data analytically. Thus, whereas for Portuguese firms organizational factors such as 'ERP use' have a great impact on value, for Spanish firms it loses importance to factors such as business analytical information.

With regards to 'ERP use', although competitive pressure, training, and best-practices are significant factors for countries, compatibility, complexity, and efficiency importance differ (Figures 2(b) and 2(c)). The underlying rationale would be that the number of years using the system shapes 'ERP use'. This conclusion might be explained through cross-country analysis.

First, although ERP best-practices (using standard protocols and few customizations) is more fitted to IS starters (Buonanno et al., 2005, Nicolaou and Bhattacharya, 2006), in connection with users trained through key-users and/or help-on-line tools, both are important drivers for ERP use in both shakedown and post golive phases. In line with Hakkinen and Hilmola (2008), poor helpdesk support and training (to reduce system complexity and create users skills), and customizations were the main barriers to best possible use of the ERP. Second, although competitive pressure is statistically significant for both Portuguese and Spanish firms, it is stronger for Spanish firms. A possible explanation is that Spanish firms have been using ERP for more years, revealing that competitive pressure is a subject where analytics plays a critical role in gaining business advantages.

Third, although compatibility and efficiency have positive paths for both countries, they are not statistically significant for Spanish firms. This can be explained by the importance that Portuguese firms confer to 
technological characteristics such as compatibility with other hardware and software, and transactional efficiency (for fast and real-time data quality, avoiding errors, higher inventories, lower profits, and nonvalue-added work), which are dependent on the system stabilization throughout the shakedown phase (Hakkinen and Hilmola, 2008; Gattiker and Goodhue, 2005).

Finally, while complexity is significant for both countries, it has a negative impact for the Portuguese firms. That is, since characteristics such as familiarity with ERP could depend on use over time, ERP starters generally have more complexity worries in manipulating the system in effective ways and obtaining worth from it. In contrast, as Spanish firms could be more familiar with ERP logic, they do not perceive system complexity as an inhibitor for ERP use.

\section{Managerial implications}

These results offer a useful framework for managers to assess post-adoption cross-country variations in usage and value of ERP. Both countries' managers should maintain priority on training programmes as well as using the ERP standard best-practices; these factors will contribute to increase skills and familiarity with the system. With the same priority, Portuguese managers should closely manage the compatibility with legacy systems and plan activities concerned with system efficiency in order to achieve greater usage and quality data. In order to create competitive advantages, both countries' managers should define strategies based on the fact that as ERP diffuses through usage and becomes a necessity to business process and organizational coverage, the competitive pressure infuses the strategic exploitation of the ERP transaction data into high value processes that are supported by new IT analytical functionalities and capabilities in areas such as collaboration throughout the supply chain. Our study also offers implications for IT industry/services. System complexity and business analytics functionalities have emerged as important factors for ERP use and value in such a way that for Portuguese SMEs familiarity is an important factor, while analytics capabilities are more important for Spanish SMEs, which implies different implementation methodologies and support contracts, alongside developing friendly front-end functionalities that extend both collaboration and analytics, yet based on standard best-practices.

\section{Research implications}

We believe this study offers implications for other researchers as well. First, we have shown that the proposed research model in Figure 1 is a useful theoretical framework for explaining determinants that affect the ERP use and value across countries and may be extended to other countries. Second, we have developed several constructs, including efficiency, which have passed convergent validity testing, and could be used in future studies. Third, supported with theory and empirical data, we have categorized two IT-enhanced capabilities (collaborations and analytics) and analysed their relative significance for ERP value. The result could serve as a theoretical base for studying additional sources of value creation derived from technology innovations.

\section{Limitations and future work}

This paper has some limitations that may form the starting point for further research. First, although our empirical results show that relationships exist among the determinants, we cannot speak empirically to the issue of whether value is sustained, because this requires a longitudinal study, so longitudinal studies could be developed. Second, although our study shows evidence that the determinants of use and value vary acrosscountries in association with the number of years using ERP, we cannot speak empirically to the issue of whether the maturity stages play a role, because this would require an adoption process life-cycle study (Holland and Light, 2001). An interesting different direction could be to study the maturity stages of ERP. Third, although data cover industry types, some biases may have been introduced. Perhaps different industries have different operating characteristics and environments, and the factors related to ERP use and value may differ accordingly (Oliveira and Martins, 2010a). Consequently, we encourage further studies that compare industries. 


\section{Conclusion}

Consistent with DOI and RBV, we developed and empirically evaluated a research model for assessing ERP use and value at the firm level. While these are usually studied separately, our study proposes that use and value are closely associated for the post-adoption stages. Besides being the first model applied to Iberian SMEs, our study contributes to the literature by moving beyond dichotomous "adoption versus non-adoption" linking actual usage to value creation, and adds transactional efficiency and collaboration as important determinants for Portuguese firms, as well as business analytics, but more important for Spanish firms. For 'ERP' use, our study has examined six DOI determinants; whereas competitive pressure, training and bestpractices are important to both Portuguese and Spanish firms, cross-country analysis also shows complexity to be an important inhibitor for 'ERP use' among Portuguese firms, but a facilitator for Spanish. In addition, while for Portuguese, compatibility and efficiency are significant, they are not for Spanish. For 'ERP value' (and consistent with RBV), our study demonstrates that the degree of 'ERP use' and IT-enhanced capabilities such as collaboration and analytics, contribute to value creation from ERP. Moreover, our study reveals that for Portuguese firms 'ERP value' is mainly explained by 'ERP use', collaboration, and analytics, whereas for Spanish firms 'ERP value' is mainly explained by collaboration and analytics capabilities. Finally, our study exposes that both countries' SMEs are not using ERPs as a transaction processing system alone, but also as a front-end application. 


\section{References}

ANTERO, M. \& RIIS, P. H. 2011. Strategic Management of Network Resources: A Case Study of an ERP Ecosystem. International Journal of Enterprise Information Systems, 7, 18-33.

BENDOLY, E. \& KAEFER, F. 2004. Business technology complementarities: impacts of the presence and strategic timing of ERP on B2B e-commerce technology efficiencies. Omega, 32, 395-405.

BHARADWAJ, A. S. 2000. A resource-based perspective on information technology capability and firm performance: An empirical investigation. MIS Quarterly, 24, 169-196.

BRADFORD, M. \& FLORIN, J. 2003. Examining the role of innovation diffusion factors on the implementation success of enterprise resource planning systems, International Journal of Accounting Information Systems. International Journal of Accounting Information Systems, 4, 205-225.

BUONANNO, G., FAVERIO, P., PIGNI, F., RAVARINI, A., SCIUTO, D. \& TAGLIAVIN, M. 2005. Factors affecting ERP system adoption: A comparative analysis between SMEs and large companies. Journal of Enterprise Information Management,, 18, 384-426.

CALISIR, F. \& CALISIR, F. 2004. The Relation of Interface Usability Characteristics, Perceived Usefulness, and Perceived Ease of Use to End-User Satisfaction with Enterprise Resource Planning (ERP) Systems. Computers in Human Behavior, 20, 505-515.

CHANG, H.-H., CHOU, H.-W., LIN, C.-P. Y. \& CECILIA, I. Year. ERP Post-Implementation Learning, ERP Usage and Individual Performance Impact. In: PACIS, ed. Pacific Asia Conference on Information Systems, July 2011 Brisbane, Australia.

CHIANG, A. 2009. Creating Dashboards: The Players and Collaboration You Need for a Successful Project Business Intelligence Journal, 14, 59-63.

CHIN, W. W. 1998. Issues and Opinion on Stuctural Equation Modeling. MIS Quarterly, 22, 7-16.

CHOU, S. W. \& CHANG, Y. C. 2008. The implementation factors that influence the ERP (enterprise resource planning) benefits. Decision Support Systems, 46, 149-157.

CHUANG, T., NAKATANI, K. \& ZHOU, D. 2009. An exploratory study of the extent of information technology adoption in SMEs: An application of Upper Echelon Theory. Journal of Enterprise Information Management, 22, 183-196.

COMMISSION, E. 2011. Annual Report on EU Small and Medium sized Enterprises 2010/2011. Available: http://ec.europa.eu/enterprise/policies/sme/facts-figures-analysis/performancereview/pdf/2010 2011/are the eus smes recovering.pdf [Accessed October 2011].

COOPER, R. \& ZMUD, R. 1990. Information Technology Implementation Research: A Technological Diffusion Approach. Management Science, 3, 123-139.

DAVENPORT, T. H. 1998. Putting the enterprise into the enterprise system. Harvard Business Review, 76, 121-131.

DAVENPORT, T. H. \& HARRIS, J. G. 2007. Competing on Analytics: The New Science of Winning, Harvard Business School Press.

DEVARAJ, S. \& KOHLI, R. 2003. Performance impacts of information technology: Is actual usage the missing link? Management Science, 49, 273-289.

ELBERTSEN, L., BENDERS, J. \& NIJSSEN, E. 2006. ERP use: exclusive or complemented? Industrial Management \& Data Systems, 106, 811-824.

FOSSER, E., LEISTER, O. H. \& MOE, C. E. Year. Organizations and vanilla software: What do we know about ERP systems and competitive advantage? In: ECIS, ed. European conference on information systems, June 2008 Galway, Irland. 2460-2471.

GATTIKER, T. F. \& GOODHUE, D. L. 2005. What happens after ERP implementation on plant-level outcomes. MIS Quarterly, 29, 559-585.

HAIR, J., ANDERSON, R., TATHAM, R. \& BLACK, W. 1998. Multivariate Data Analysis, New Jersey, Prentice Hall.

HÄKKINEN, L. \& HILMOLA, O.-P. 2008. Life after ERP implementation: Long-term development of user perceptions of system success in an after-sales environment. Journal of Enterprise Information Management, 21, 285 - 310.

HEDMAN, J. \& KALLING, T. 2003. The business model concept: theoretical underpinnings and empirical illustrations. European Journal of Information Systems, 12, 49-59.

HITT, L. M., WU, D. J. \& ZHOU, X. 2002. Investment in enterprise resource planning: business impact and productivity measures. Journal of Management Information Systems, 19, 71-98.

HO, C. \& TAI, Y. 2004. Strategies for the adaptation of ERP systems. Industrial Management \& Data Systems, 104, 234-251.

HOLLAND, C. P. \& LIGHT, B. 2001. A stage maturity model for enterprise resource planning systems use. SIGMIS Database, 32, 34-45. 
KLAUS, H., ROSEMANN, M. \& GUY, G. G. 2000. What is ERP? Information Systems Frontiers, 2, 141162.

KOSITANURIT, B., NGWENYAMA, O. \& OSEI-BRYSON, K. 2006. An exploration of factors that impact individual performance in an ERP environment: An analysis using multiple analytical techniques. European Journal of Information Systems, 15, 556-568.

LIANG, H., SARAF, N., HU, Q. \& XUE, Y. 2007. Assimilation of enterprise systems: the effect of institutional pressures and the mediating role of top management. MIS Quarterly, 31, 59-87.

LIGHT, B. \& PAPAZAFEIROPOULOU, A. 2004. Reasons Behind ERP Package Adoption: A Diffusion of Innovations Perspective. 13th European Conference on Information Systems. Turku, Filand.

MABERT, A., SONI, A. \& VENKATARAMANAN, M. A. 2001. Enterprise resource planning: measuring value. Production Inventory Management Journal, 42, 46-52.

MAGUIRE, S., OJIAKO, U. \& SAID, A. 2010. ERP implementation in Omantel: a case study. Industrial Management \& Data Systems, 110, 78-92.

MALHOTRA, N. \& BIRKS, D. 2007. Marketing Research: An Applied Approach, Edinburg, Financial Times Press.

MATA, F. J., FUERST, W. L. \& BARNEY, J. B. 1995. Information technology and sustained competitive advantage: A resource-based analysis. MIS Quarterly, 9, 487-505.

NAH, F., TAN, X. \& THE, S. H. 2004. An Investigation on End-Users Acceptance of Enterprise Systems. Information Resources Management Journal, 17, 32-53.

NICOLAOU, A. \& BHATTACHARYA, S. 2006. Organizational performance effects of ERP systems usage: the impact of post implementation changes. International Journal of Accounting Information Systems, 7, $18-35$.

O'LEARY, D. 2000. Enterprise resource planning: systems, life cycle, electronic commerce, and risk, New York: Cambridge, Univ. Press.

OLIVEIRA, T. \& MARTINS, M. F. 2010a. Firms Patterns of E-business Adoption: Evidence for the European Union-27. The Electronic Journal Information Systems Evaluation, 13, 47-56.

OLIVEIRA, T. \& MARTINS, M. F. 2010b. Understanding e-business adoption across industries in European countries Industrial Management \& Data Systems, 110, 1337-1354.

PARK, J. H., SUH, H. J. \& YANG, H. D. 2007. Perceived absorptive capacity of individual users in performance of enterprise resource planning (ERP) usage: The case for Korean firms. Information \& Management, 44, 300-312.

RAJAGOPAL, P. 2002. An innovation-diffusion view of implementation of enterprise resource planning (ERP) systems and development of a research model. Information \& Management, 40.

RAYMOND, L. \& UWIZEYEMUNGU, S. 2007. A profile of ERP adoption in manufacturing SMEs. Journal of Enterprise Information Management, 20, 487-502.

RHODES, J., P. LOK, YANG, S. \& BAMBACAS, M. 2009. Resource based view of intangibles on ERP systems implementation and organizational performance in China. Journal of Global Strategic Management, 5, 87-96.

ROGERS, E. M. 1995. Diffusion of innovations, New York, The Free Press.

RUIVO, P. \& NETO, M. Year. Sustainable enterprise KPIs and ERP post-adoption. In: Conference Information Systems and Technologies, June 2011 Chaves - Portugal. CISTI.

SHAHIN, D. \& AININ, S. 2011. The influence of organizational factors on successful ERP implementation. Management Decision, 49, 911-926.

VELCU, O. 2007. Exploring the effects of ERP systems on organizational performance: evidence from Finnish companies. Industrial Management \& Data Systems, 107, 1316-1334.

WAARTS, E., VAN-EVERDINGEN, Y. \& VAN-HILLEGERSBERG, V. 2002. The dynamics of factors affecting the adoption of innovations. Journal of Product Innovation Management, 19, 412-423.

WENRICH, K. \& AHMAD, N. 2009. Lessons learned during a decade of ERP experience: A case study. International Journal of Enterprise Information Systems, 5, 55-73.

YU, C.-S. 2005. Causes influencing the effectiveness of the post-implementation ERP system, Industrial Management \& Data Systems. Industrial Management \& Data Systems, 105, 115-132.

ZHANG, Z., LEE, M. K. O., HUANG, P., ZHANG, L. \& HUANG, X. 2005. A framework of ERP systems implementation success in China: An empirical study. International Journal of Production Economics, 98, 56-80.

ZHU, K. \& KRAEMER, K. L. 2005. Post-adoption variations in usage and value of e-business by organizations: Cross-country evidence from the retail industry. Information Systems Research, 16, 61-84. 


\section{Appendix A. Items measurements}

\begin{tabular}{|c|c|c|}
\hline \multicolumn{2}{|c|}{$\begin{array}{l}\text { Variable } \\
\text { Indicators } \\
\text { Using a five-point scale, where 1 means 'low' and } 5 \text { 'high', respondents* were asked to rate their perception. }\end{array}$} & Literature support \\
\hline $\begin{array}{l}\text { Complexity } \\
\text { (reverse code) }\end{array}$ & $\begin{array}{l}\text { According to users' interaction with ERP, please rate... } \\
\text { CX1 ... how easy it is for them to learn the system.** } \\
\text { CX2 ...the intuitiveness of the system. } \\
\text { CX3 ...how comfortable they feel using it. }\end{array}$ & $\begin{array}{l}\text { Cooper and Zmud, 1990; } \\
\text { Kositanurit } \text { et al., 2006; } \\
\text { Chang } \text { et al., } 2011\end{array}$ \\
\hline Efficiency & $\begin{array}{l}\text { According to users' interaction with ERP, please rate the... } \\
\text { EF1 ...effectiveness in executing repetitive tasks. } \\
\text { EF2 ...effectiveness of user interface. } \\
\text { EF3 ....speed and reliability of system. }\end{array}$ & $\begin{array}{l}\text { Rajagopal } \text { et al., 2002; } \\
\text { Bendoly } \text { et al., 2004; } \\
\text { Gattiker } \text { et al., } 2005\end{array}$ \\
\hline Best Practice & $\begin{array}{l}\text { According to ERP standard package (best-practices) fitting firm's processes, please rate the degree... } \\
\text { BP1 ...to which users set up the application. } \\
\text { BP2 ...to which one can map workflows based on local requirements (such as VAT, intercompany posting). } \\
\text { BP3 ...of system adaptability to business needs. }\end{array}$ & $\begin{array}{l}\text { Chou and Chang, 2008; } \\
\text { Wenrich and Ahmad, 2009; } \\
\text { Maguire } \text { et al., } 2010\end{array}$ \\
\hline $\begin{array}{l}\text { Competitive } \\
\text { Pressure }\end{array}$ & $\begin{array}{l}\text { Please rate the degree to which ... } \\
\text { CP1 ... your firm has experienced competitive pressure to use ERP. } \\
\text { CP2 ... your firm would have experienced competitive disadvantage if ERP had not been adopted.* } \\
\text { CP3 ... the ERP usage in your firm's competitors affects your landscape market. }\end{array}$ & $\begin{array}{l}\text { Bradford and Florin, 2003; } \\
\text { Zhu et al., 2004; Oliveira } \\
\text { and Martins, 2010b }\end{array}$ \\
\hline ERP Use & $\begin{array}{l}\text { According to ERP usage how... } \\
\text { ERPU1 ...many employees use the system daily? }(\#)^{* *} \\
\text { ERPU2 ...much time per day do employees work with the system? (\%) } \\
\text { ERPU3 ...many reports are generated per day? }(\%)\end{array}$ & $\begin{array}{l}\text { Bradford and Florin, 2003; } \\
\text { Devaraj and Kohli, 2003; } \\
\text { Zhu and Kraemer, 2005 }\end{array}$ \\
\hline Collaboration & $\begin{array}{l}\text { According to users, please rate the degree of how ease for them } \ldots \\
\mathrm{CO} 1 \ldots \text { collaborate with colleagues. } \\
\mathrm{CO} 2 \ldots \text { collaborate with the system. } \\
\mathrm{CO} 3 \ldots \text { communicate with suppliers, partners, and customers. }\end{array}$ & $\begin{array}{l}\text { Calisir and Calisir, 2004; } \\
\text { Gattiker and Goodhue, } \\
2005 ; \text { Ruivo and Neto, } \\
2010\end{array}$ \\
\hline $\begin{array}{l}\text { ERP Value } \\
\text { (firm } \\
\text { performance) }\end{array}$ & $\begin{array}{l}\text { Please rate the degree of ERP impact on... } \\
\text { ERPV1 ...user satisfaction. } \\
\text { ERPV2 ... individual productivity. } \\
\text { ERPV3 ...customer satisfaction. } \\
\text { ERPV4 ... management control. }\end{array}$ & $\begin{array}{l}\text { Bradford and Florin, 2003; } \\
\text { Devaraj and Kohli, 2003; } \\
\text { Zhu and Kraemer, 2005; } \\
\text { Shahin and Ainin, 2011 }\end{array}$ \\
\hline
\end{tabular}

* Respondents types were: CEO, owner, IT/IS manager, Finance manager, Sales manager and Manufacturing manager

** CB3, CX1, TN1, CP2, and ERPU1 question-items were excluded after PLS model estimation due to low loadings. 